Scientific Review - Engineering and Environmental Sciences (2021), 30 (4), 552-560

Sci. Rev. Eng. Env. Sci. (2021), 30 (4)

Przegląd Naukowy - Inżynieria i Kształtowanie Środowiska (2021), 30 (4), 552-560

Prz. Nauk. Inż. Kszt. Środ. (2021), 30 (4)

https://srees.sggw.edu.pl

DOI 10.22630/PNIKS.2021.30.4.46

Nur Muizzah NAWI, Doris Asmani MAT YUSOF,

Siti Shahidah SHARIPUDIN, Nora Farina MOHD HALIM,

Nor Mayuze MOHAMAD

Universiti Teknologi MARA, College of Engineering

\title{
Study on potential of soil stabilization using concrete sludge of batching plant (CSBP)
}

Key words: CBR value, concrete sludge, organic soil, maximum dry density, subgrade

\section{Introduction}

Malaysia's construction sector is fast developing as it moves closer to being a developed country. The expansion of new buildings and infrastructure in this country aided the expansion of manufacturing factories to meet the demand for materials for such projects. As concrete is one of the primary materials used in most construction projects, the number of batching plants in Malaysia will grow as ready-mix concrete is preferred to be used by the construction industry.

Traditionally, concrete mix design for casting in-situ must include a certain amount of allowable wastage for the materials as well as ready-mix concrete. The ready-mix concrete was one of the most wasteful materials, estimated to be $12 \%$ and will eventually be returned to the batching plants as concrete sludge (Arshad, Qasim, Thaheem \& Gabriel, 2017). Unfortunately, the batching plant lacks an appropriate disposal solution for the returning concrete sludge. A research conducted in 2016 that looked at the current techniques for using fresh concrete waste returning to batching plants may have solved the problem. Kazaz and U1ubeyli (2016) concluded that there are nine techniques for benefitting batching plant returned concrete sludge. Discharging to the ground is the most common method utilized by batching plants out of all the options.

As a solution, several studies have been conducted to recycle the returned concrete sludge of batching plants (Arunvivek, Maheswaran, Senthil Kumar, Senthilkumar \& Bragadeeswaran, 2015; Vieira \& de Figueiredo, 2016; Thorneycroft, Orr, Savoikar \& Ball, 2018). According to a study conducted by Vieira and de Figueiredo (2016) in Brazil, crushing 
hardened concrete to generate recycled aggregates is one of the ways that may be utilized to tackle the problem (Vieira \& de Figueiredo, 2016). On the other hand, Arunvivek et al. (2015) found that concrete containing $15-30 \%$ recycled fresh concrete waste is excellent for generating standard strength concrete.

There is a global need for developments of method used to utilize the waste that came from the batching plant. The search for environmentally, sustainably, and economically solution for the final disposal of concrete sludge from the batching plant is a challenge. At present the main concern is to dispose this waste correctly and reducing the storage costs hence promote sustainable waste management (Tewar, Shah \& Patel, 2017). Many studies have shown that this concrete sludge can be used as recycled concrete (Arunvivek et al., 2015; Vieira \& de Figueiredo, 2016; Thorneycroft et al., 2018; Nawi et al., 2019).

Three type of cementitious materials was tested and the result show that the combination of fly ash and Portland cement was the most effective stabilizer to acquire higher strengths (Tavakol, Hossain \& Tucker-Kulesza, 2019). As the characteristics of CSBP and fly ash are almost the same which more on cementitious behavior, this research is to aim for the potential of soil-CSBP mixture to be use as subgrade soil stabilizer (Chattaraj \& Sengupta, 2017; Tewar et al., 2017).

The strength behavior of soil with fly ash is identified by examining the influence of fly ash on the consistency, compactness, acidic characteristics, and strength of organic soil, according to Nath, Molla, Ali and Sarkar (2017). The plasticity index of organic soil is consid- erably reduced by fly ash, but the liquid and plastic limits rise. Aside from that, the properties of organic soil are enhanced, but the extent of the improvement is dependent on the organic soil's features as well as the properties and amount of fly ash (Nath et al., 2017).

Anupam, Kumar, Ransinchung and Shah (2017) has conducted a study to investigate the usefulness of industrial waste which are fly ash and bagasse ash as a soil admixture. The physical and chemical properties of these waste was examined by using California bearing ratio test, unconfined compressive strength and triaxial test. It shows that combination of fly ash and bagasse ash increased the unconfined compressive strength of the soil significantly thus can improve the load bearing capacity of the soil (Anupam et al., 2017).

The use of additional material for subgrade improvement was extend not only to roadwork but also on airfield pavements. Basically, lime, fly ash, cement and several combinations of these material were utilized as the stabilized agent for the soils. The best stabilized agent was depending on the soil characteristics itself, but nevertheless fly ash was use at two of the airports with the addition of $12-14 \%$ and the CBR value is reported to increase approximately 20 . Plus, the fly ash is cheaper and easier to find compare to produce cement (Ward, Taylor \& Grubbs, 2017). This supports the usage of recycle material as fly ash and CSBP has a problematic issue related to the disposal method of the material.

Preliminary study shows that the replacement of cement by $20 \%$ of CSBP in concrete achieved the favorable compressive strength (Nawi et al., 2019). 
According to the findings, CSBP has the potential to be employed as a sustainable recycled material in traditional concrete. To extend the potential of CSBP as the recycled material in construction industry, it is to be proposed to use as the subgrade stabilization agent for pavement construction. A study conducted by Bandara, Binoy, Aboujrad and Sato (2015) has used cement, lime, and fly ash as the recycled material for subgrade stabilization to identify long term benefit for optimizing pavement design yet also lessen landfill problems. Since the properties of CSBP are comparable to those of fly ash, it is proposed in this study that CSBP be used as a recycled material for subgrade stabilization in pavement construction.

As CSBP can be categorized as one of the sustainable recycled materials, it is expected that by adding certain amount of CSBP in soil can increase the strength of the proposed soil. This study evaluates the use of CSBP as an additive for soil in subgrade layer for pavement construction as CSBP will act as a stabilizing agent of the soil mixture. At the same time, it promotes the proper and sustainable way to dispose CSBP rather than dispose them to landfill as well as reducing the cost of stabilizer agent for soil improvement as CSBP is a recycled material which incurred low processing cost.

\section{Material and methods}

The purpose of this study was to look at the performance of stabilized-organic soil at various CSBP percentages which are $0,5,10$ and $15 \%$ based on the earlier study that performed by Kumar and Harika (2021). Instead of using fly ash, CSBP were used as it gives the similar cementitious characteristic as fly ash. In that study, the combination of $10 \%$ of fly ash gives the optimum value of CBR to the treated soil (Kumar \& Harika, 2021). This study then was further tested to identify the index properties of the soil, compaction characteristic and California bearing ratio (CBR) characteristics.

\section{Organic soils}

The organic soil sample was collected at a depth of $0.5-1.0 \mathrm{~m}$ below the present ground surface from a local source in Pasir Gudang, Johor, Malaysia. The soil sample was then transferred to the laboratory and oven-dried at $105^{\circ} \mathrm{C}$ for about $48 \mathrm{~h}$ before laboratory testing is conducted.

\section{Concrete sludge of batching plant (CSBP)}

Concrete sludge of batching plant is a fresh concrete waste that returned to the batching plants and was collected from Lafarge concrete batching plant which located at Pengerang, Kota Tinggi Johor. The CBSP was transported to the laboratory and oven-dried at $105^{\circ} \mathrm{C}$ for about $48 \mathrm{~h}$. Then, the dry CSBP was manually crushed with a rubber hammer and sieved through a $0.475 \mathrm{~mm}$ sieve (in powder form) as in Figure 1.

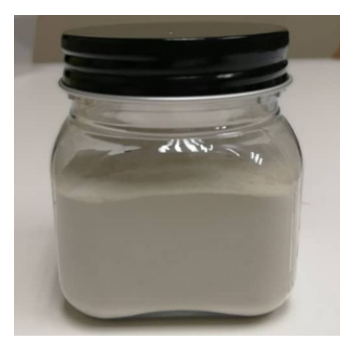

FIGURE 1. Physical appearance of CSBP after sieved 


\section{General laboratory testing method}

In general, multiple laboratory experiments were conducted in this study to assess the efficiency of CSBP in improving the performance of local problematic organic soil in Pasir Gudang, Johor. To identify and categorize the soil characteristic, the particle size distribution (PSD), Atterberg limit test, and specific gravity test were used. The materials were then subjected to a standard proctor compaction test to establish their optimum moisture content (OMC) and maximum dry density (MDD) values. Finally, a California carrying ratio (CBR) test was performed to assess the soil's load bearing capability in an unsoaked condition. All tests were carried out in accordance with the British standard BS 1377-2:1990 (British Standards Institution [BSI], 2004).

\section{Results and discussion}

\section{Index properties of soil}

Table 1 summarizes the index properties of organic soil that were used in this investigation to identify and classify soil characteristics. Atterberg limit test is conducted to determine the plasticity index (PI) value based on plastic limit (PL) and liquid limit (LL) result data. Table 1 shows that the LL and the PL of the soil used throughout this study are 69 and $62 \%$, respectively. Hence, the PI data is verified as $7 \%$. Based on the plasticity chart for soil classification given in Figure 2, the soil was classified as an organic of high plasticity $(\mathrm{OH})$. The specific gravity of soil used is 2.3, which was classified as organic soil as outlined in the British standard BS 1377-2:1990.

TABLE 1. Index properties of organic soils

\begin{tabular}{|l|c|}
\hline Index properties & Value \\
\hline Liquid limit (LL) [\%] & 69.00 \\
\hline Plastic limit (PL) [\%] & 62.00 \\
\hline Plasticity index (PI) [\%] & 7.00 \\
\hline Specific gravity & 2.30 \\
\hline
\end{tabular}

\section{Compaction characteristic}

The optimum moisture content (OMC) and maximum dry density (MDD) relationships for the various percentages of CSBP $(0,5,10$, and $15 \%)$ were determined using the standard proctor compaction test. As in Figure 3, it shows the results of the standard proctor compaction test comparing dry density and moisture content at various percentages of CSBP. While data shows that the original organic soil sample has OMC value of $38.05 \%$, while the OMC value of stabilized soil with 5,10 , and $15 \%$ of CSBP are $36.94,35.33$, and $31.58 \%$, respectively (Table 2). However, the MDD value of the original organic soil sample is $1.12 \mathrm{Mg} \cdot \mathrm{m}^{-3}$ while for stabilized soil with 5, 10, and $15 \%$ of CSBP are $1.13,1.15$, and $1.22 \mathrm{Mg} \cdot \mathrm{m}^{-3}$, respectively. The OMC value decreases with the addition of CSBP, whereas the MDD value increases. However, the increases of MDD values does not show such a significant difference. 


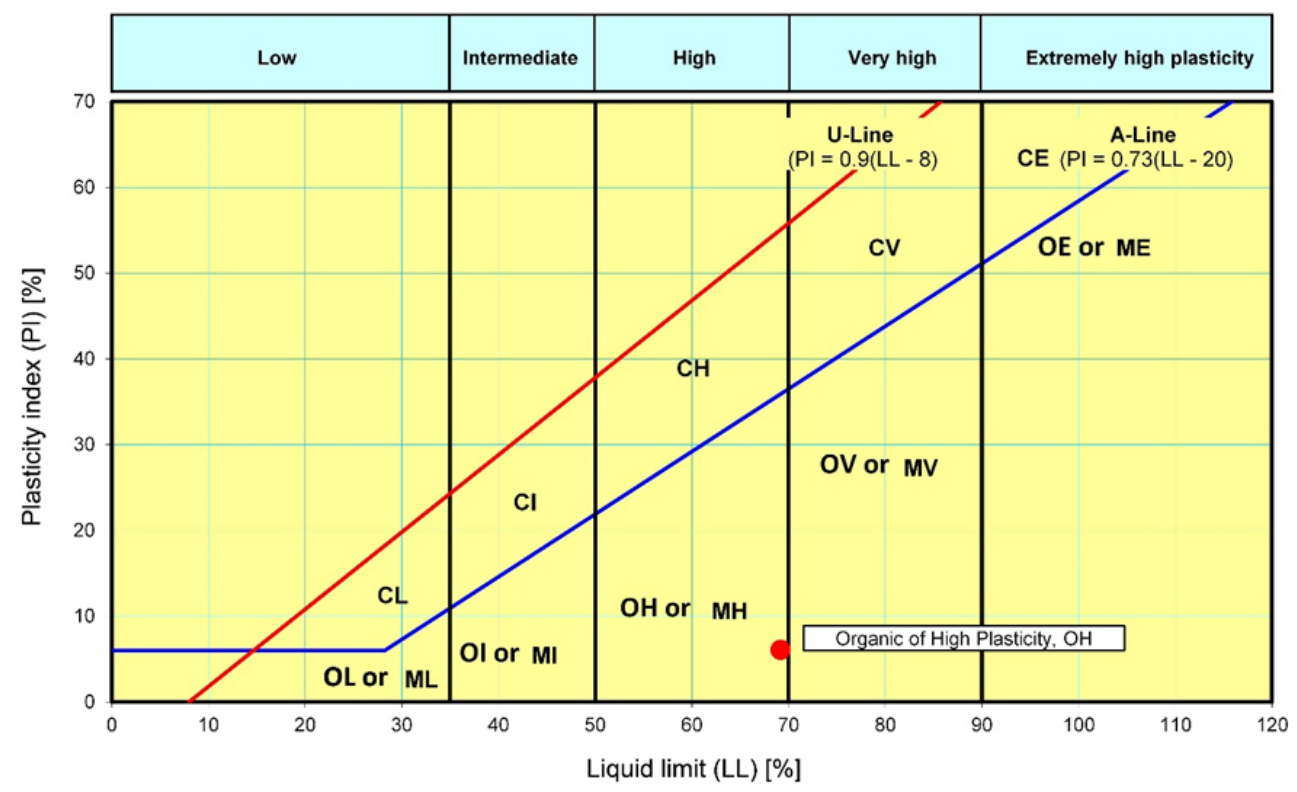

FIGURE 2. Plasticity chart for the soil classification
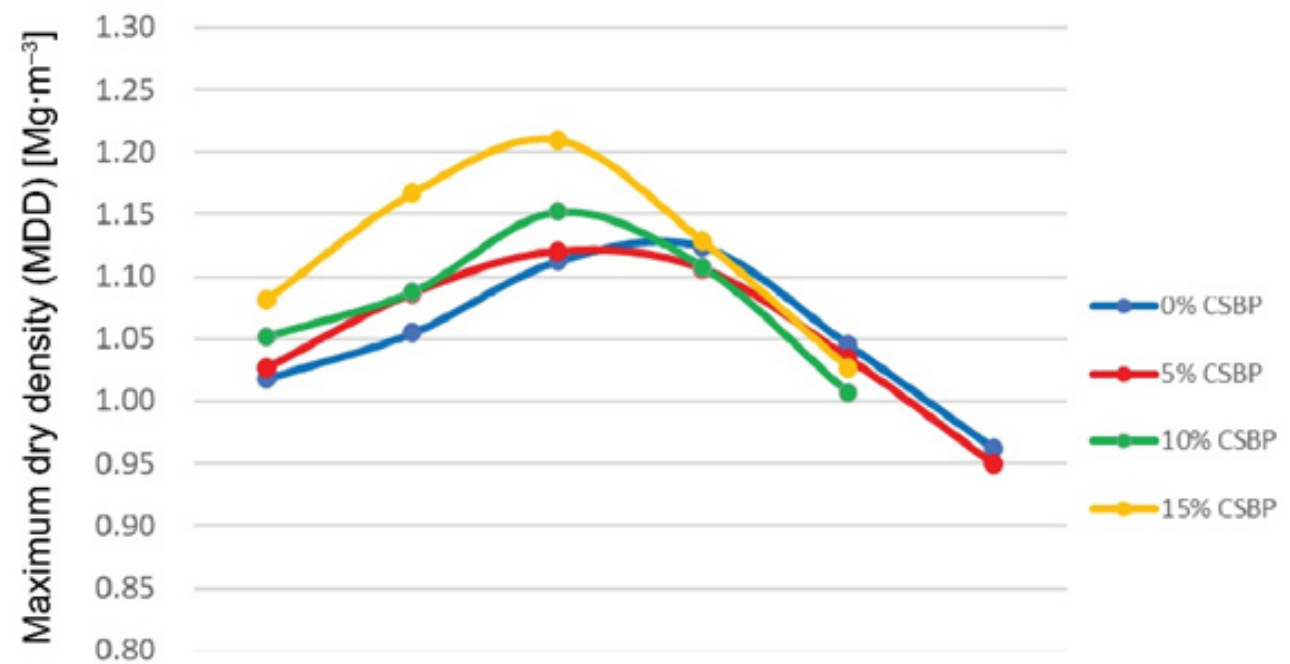

.80

10

20

30

40

50

60

\section{Optimum moisture content (OMC) [\%]}

FIGURE 3. Optimum moisture content (OMC) and maximum dry density (MDD) relationship compaction curve 
TABLE 2. Optimum moisture content (OMC) and maximum dry density (MDD) values of compaction test

\begin{tabular}{|l|c|c|}
\hline $\begin{array}{l}\text { CSBP ratio } \\
{[\%]}\end{array}$ & $\begin{array}{c}\text { OMC value } \\
{[\%]}\end{array}$ & $\begin{array}{c}\text { MDD value } \\
{\left[\mathrm{Mg} \cdot \mathrm{m}^{-3}\right]}\end{array}$ \\
\hline 0 & 38.05 & 1.12 \\
\hline 5 & 36.94 & 1.13 \\
\hline 10 & 35.33 & 1.15 \\
\hline 15 & 31.58 & 1.22 \\
\hline
\end{tabular}

\section{California bearing ratio (CBR) characteristics}

The CBR characteristic was used to analyse the effect of CSBP on stabilised soil strength. The CBR test was carried out in unsoaked conditions by measuring the force required to penetrate a soil sample with a plunger in order to estimate the soil's load bearing capability. The CBR values for the load that corresponds to the $2.5 \mathrm{~mm}$ and $5.0 \mathrm{~mm}$ penetration are recorded as summarized in Table 3, and generally the greater value has been accepted as CBR value. Thus, according to the findings the CBR values at $5.0 \mathrm{~mm}$ penetration are found to be greater than those at $2.5 \mathrm{~mm}$ penetration.

Figure 4 shows the relationship between load and penetration at various CSBP percentages. From the plotted graph, the load and penetration curve show that the CBR value at $5.0 \mathrm{~mm}$ has increased by $4.8,7.4,13.2$, and $20.7 \%$ with the addition in CSBP percentages of $0,5,10$, and $15 \%$, respectively. According to the data obtained, the subgrade category, SG for organic soil change from SG1 to SG2 and SG3 due to increases amount percentage of CSBP (Malaysia Public Work Department, 2008). Because of the cement content in the sludge, which is made of lime, silica, and alumina, which gives specific features in soil stabilisation, it can be deduced that the strength of stabilised soil increased with the elevation percentage of CSBP (Shalabi et al., 2019). Furthermore, Akbar et al. (2020) has concluded that concrete sludge waste has the potential to modify the engineering behaviour of high plasticity soil and significantly increase the CBR value of stabilised soil to meet the requirement for road-base material.

TABLE 3. California bearing ratio (CBR) value at $2.5 \mathrm{~mm}$ and $5.0 \mathrm{~mm}$ penetration

\begin{tabular}{|l|c|c|}
\hline $\begin{array}{l}\text { CSBP ratio } \\
{[\%]}\end{array}$ & $\begin{array}{c}\text { CBR at } 2.5 \mathrm{~mm} \\
\text { penetration } \\
{[\%]}\end{array}$ & $\begin{array}{c}\text { CBR at } 5.0 \mathrm{~mm} \\
\text { penetration } \\
{[\%]}\end{array}$ \\
\hline 0 & 3 & 4.8 \\
\hline 5 & 4.3 & 7.4 \\
\hline 10 & 8.4 & 13.2 \\
\hline 15 & 15.6 & 20.7 \\
\hline
\end{tabular}

\section{Conclusions}

This study offers the preliminary results of using concrete sludge of batching plant (CSBP) for soil stabilization and modification of an organic soil sample. An organic soil sample used can be graded as an organic of high plasticity $(\mathrm{OH})$. Thus, soil improvement needs to meet specific requirement in subgrade pavement design in standard specification for road work of Malaysia Public Work Department (2008). Compacted soil samples with various CSBP percentages were tested to see if CSBP has the ability to change the engineering behavior of organic soil and make it suitable for subgrade. 


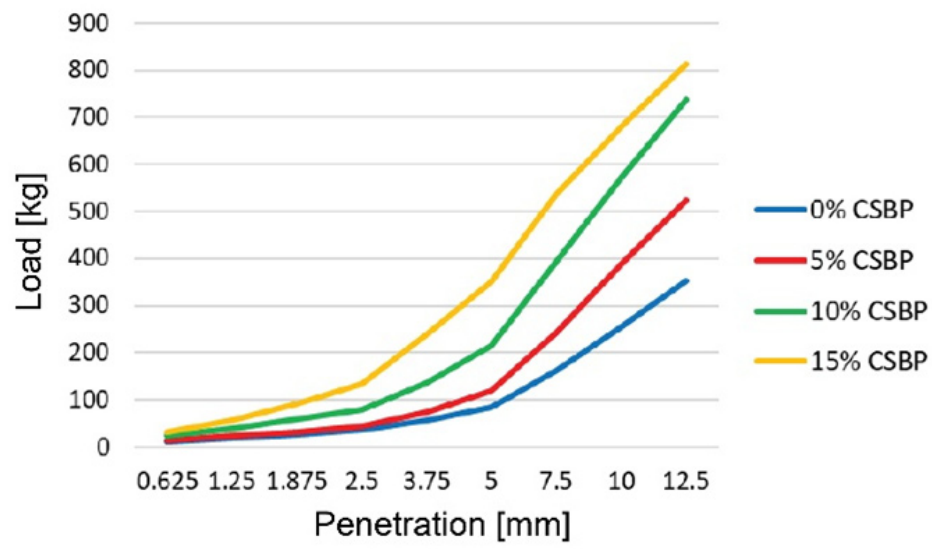

FIGURE 4. Load and penetration curve at different concrete sludge of batching plant (CSBP) percentages

With the growth in CSBP percentages from 0 to $15 \%$, the CBR value increases considerably from 4.8 to $20.7 \%$. The CBR values have revealed a possible increasing trend of strength of stabilised soil samples as the percentage of CSBP has increased. In this study, CSBP has shown its potential as a stabilization material in increasing CBR value for subgrade pavement. Subsequently, the utilize of CSBP in organic soil stabilization is an inventive thought due to a couple of reasons, counting being able to retain water, and sustainable practice where it is great for the environment impacts as well as to diminish costs at batching plant. Other than that, utilize of CSBP will advance the natural motivating forces to supply a way to reuse huge amounts of waste materials for highway engineering resolutions.

\section{Acknowledgements}

The authors are grateful to Universiti Teknologi MARA, Cawangan Johor for providing research funding through
Geran Bestari Phase 1/2020 and Lafarge Concrete Industries Sdn Bhd, Malaysia, for providing the materials for the study.

\section{References}

Akbar, N.A., Ismail, T.N.H.T., Adnan, S.H., Yusop, F.M., Khosran, H. \& Saji, N. (2020). Improvement in CBR Value of Sub-Base Soil using Concrete Slush Waste (CSW). Journal of Advanced Industrial Technology and Application, 1(1), 48-56.

Anupam, A.K., Kumar, P., Ransinchung, G.D. \& Shah, Y.U. (2017). Study on performance and efficacy of industrial waste materials in road construction: fly ash and bagasse ash. Airfield and Highway Pavements, 2017, 45-56.

Arshad, H., Qasim, M., Thaheem, M.J. \& Gabriel, H.F. (2017). Quantification of material wastage in construction industry of Pakistan: An analytical relationship between building types and waste generation. Journal of Construction in Developing Countries, 22(2), 19-34.

Arunvivek, G.K., Maheswaran, G., Senthil Kumar, S., Senthilkumar, M. \& Bragadeeswaran, T. (2015). Experimental study on influence of recycled fresh concrete waste coarse aggregate on properties of concrete. International 
Journal of Applied Engineering Research, 10(11), 29809-29815.

Bandara, N., Binoy, T.H., Aboujrad, H.S. \& Sato, J. (2015). Pavement subgrade stabilization using recycled materials. Airfield and Highway Pavements, 2015, 605-616.

British Standards Institution [BSI] (2004). Methods of test for soils for civil engineering purposes. Part 2: Classification tests (BS 1377-2:1990). Chiswick: British Standards Institution.

Chattaraj, R. \& Sengupta, A. (2017). Dynamic properties of fly ash. Journal of Materials in Civil Engineering, 29(1), 04016190. https://doi.org/10.1061/(ASCE)MT.19435533.0001712

Kazaz, A. \& Ulubeyli, S. (2016). Current methods for the utilization of the fresh concrete waste returned to batching plants. Procedia Engineering, 161, 42-46.

Kumar, P.G. \& Harika, S. (2021). Stabilization of expansive subgrade soil by using fly ash. $M a-$ terials Today: Proceedings, 45, 6558-6562.

Malaysia Public Work Department (2008). Standard Specification for Road Works. Section 4. Flexible Pavement. Kuala Lumpur: Kerja Raya Malaysia.

Nawi, N.M., Mat Yusof, D.A., Sharipudin, S.S., Mohd Halim, N.F., Mohamad, N.M. \& Shafie, M.Z. (2019). The utilization of concrete sludge of batching plant (CSBP) as a partial cement replacement in concrete. International Journal of Engineering \& Technology, 8(3), 257-260.

Nath, B.D., Molla, M., Ali, K. \& Sarkar, G. (2017). Study on Strength Behavior of Organic Soil Stabilized with Fly Ash. International Scholarly Research Notices, 2017, 5786541. https://doi.org/10.1155/2017/5786541

Shalabi, F.I., Mazher, J., Khan, K., Alsuliman, M., Almustafa, I., Mahmoud, W. \& Alomran, N. (2019). Cement-stabilized waste sand as sustainable construction materials for foundations and highway roads. Materials, 12(4), 600. https://doi.org/10.3390/ ma12040600

Tavakol, M., Hossain, M. \& Tucker-Kulesza, S.E. (2019). Subgrade soil stabilization using low-quality recycled concrete aggregate. In Geo-Congress 2019: Geotechnical Materials, Modeling, and Testing (pp. 235-244).
Reston, VA: American Society of Civil Engineers.

Tewar, B., Shah, P.M. \& Patel, P.B. (2017). Effect of Partial Replacement of Sand with Wastage of Manufactured AAC Block in Concrete. Materials Today: Proceedings, 4(9), 9817$-9821$.

Thorneycroft, J., Orr, J., Savoikar, P. \& Ball, R.J. (2018). Performance of structural concrete with recycled plastic waste as a partial replacement for sand. Construction and Building Materials, 161, 63-69.

Vieira, L.D.B.P. \& Figueiredo, A.D. de (2016). Evaluation of concrete recycling system efficiency for ready-mix concrete plants. Waste Management, 56, 337-351.

Ward, T., Taylor, A. \& Grubbs, J. (2017). A comparison of subgrade improvement methods. International Conference on Highway Pavements and Airfield Technology, 2017, 173-184.

\section{Summary}

Study on potential of soil stabilization using concrete sludge of batching plant (CSBP). More than $8 \mathrm{t}$ of fresh concrete waste may be created and returned to the batching plants throughout Malaysia, where it will degrade into concrete sludge. Most batching plants will dump their concrete sludge on the ground or at a landfill which is not eco-friendly at all. Consequently, this study is to investigate the potential of concrete sludge of batching plant (CSBP) to be used as the stabilized material for organic soil which indirectly can help to recycle CSBP from end up at the landfill. The Atterberg limit test was conducted to identify the characteristic of soil used in this study. Four different percentages of CSBP were used which are $0,5,10$ and $15 \%$. Then, the standard Proctor test and California bearing ratio test were performed, and it shows that the CBR value remarkably increases from 4.8 to $20.7 \%$, with the rise of CSBP percentages from 0 to $15 \%$. The finding shows that CSBP can be used as the potential material to 
enhance the trend of strength value of CBR. Thus, using CSBP as a stabilized material for organic soil would alleviate the problem of overflowing landfills with concrete sludge and encourage a more sustainable approach in the construction industry.

\section{Authors' address:}

Nur Muizzah Nawi - corresponding author Universiti Teknologi MARA

College of Engineering

School of Civil Engineering

Cawangan Johor, Pasir Gudang Campus

81750 Masai, Johor

Malaysia

e-mail:nmuizzah@uitm.edu.my

Doris Asmani Mat Yusof

Universiti Teknologi MARA

College of Engineering

School of Civil Engineering

Cawangan Johor, Pasir Gudang Campus

81750 Masai, Johor

Malaysia

e-mail: dorisasmani@uitm.edu.my
Siti Shahidah Sharipudin

Universiti Teknologi MARA

College of Engineering

School of Civil Engineering

Cawangan Johor, Pasir Gudang Campus

81750 Masai, Johor

Malaysia

e-mail: shahidahs@uitm.edu.my

Nora Farina Mohd Halim

Universiti Teknologi MARA

College of Engineering

School of Civil Engineering

Cawangan Johor, Pasir Gudang Campus

81750 Masai, Johor

Malaysia

e-mail:norafarina@uitm.edu.my

Nor Mayuze Mohamad

Universiti Teknologi MARA

College of Engineering

School of Civil Engineering

Cawangan Johor, Pasir Gudang Campus

81750 Masai, Johor

Malaysia

e-mail: norma7544@uitm.edu.my 